\title{
Plasmid macro-evolution: selection of deletions during adaptation in a nutrient- limited environment
}

\author{
R. I. Modi ${ }^{1}$, C. M. Wilke, R. F. Rosenzweig \& J. Adams ${ }^{2}$ \\ Department of Biology, University of Michigan, Ann Arbor, MI 48109, USA \\ ${ }^{1}$ Present address: Cadila Laboratories, Ahmedabad-380008, Gujarat, India \\ ${ }^{2}$ To whom reprint requests should be addressed
}

Received 17 May $1991 \quad$ Accepted in revised form 18 July 1991

Key words: Coevolution, tetracycline-resistance, Escherichia coli, pBR322, plasmid deletion

\begin{abstract}
Under conditions where plasmid-carriage is deleterious to the cell, evolutionary changes may be expected which result in an attenuation of the deleterious effect of the plasmid. During long-term growth in glucose-limited continuous culture, initiated with a single clone of Escherichia coli containing a derivative of the plasmid pBR322, a structural change arose in the plasmid and predominated in the plasmid-containing sector of the population. This variant possessed a $2.25 \mathrm{~kb}$ deletion encompassing the tetracycline resistance operon as well as a region of about 1.5 $\mathrm{kb}$ upstream from this operon. Competition experiments involving strains carrying the plasmid with the spontaneous deletion, and strains carrying plasmids with artificially constructed deletions, revealed that deletion of this region of the plasmid, involving loss of tetracycline resistance, resulted in an increment in fitness of between 10 and $20 \%$. From the magnitude of the growth advantage, we conclude that the attenuation of the deleterious effect of the plasmid was mainly due to a reduction in the plasmid mediated interference in the metabolism of the cell caused by a deletion of the tetracycline resistance gene.
\end{abstract}

\section{Introduction}

There is now abundant evidence that the presence of a plasmid in a bacterial cell almost invariably depresses growth rate, in the absence of an environmental agent (such as an antibiotic) which specifically selects for the presence of the plasmid. Such growth-rate depression has been documented for R plasmids (Melling, Ellwood \& Robinson, 1977; Engberg \& Nordstrom, 1978; Godwin \& Slater, 1979; Zund \& Lebek, 1980; Wouters \& van Andel, 1983) as well as for small non-conjugative ColEI-type plasmids (Inselburg, 1978; Jones et al., 1980; Roth, Muller \& Noack, 1980; Wouters et al., 1980; Helling, Kinney \& Adams, 1981; Noack et al., 1981; Boe, Gerdes \& Molin, 1987; Chiang \& Bremer, 1988), though there are one or two notable exceptions (Lundquist \& Levin, 1986; Wou- ters \& van Andel, 1983). Furthermore, an increase in plasmid size has been observed to lead to a greater degree of growth rate depression (Weinberger \& Helmstetter, 1979; Noack et al., 1981; Warnes \& Stephenson, 1986; Zund \& Lebek, 1986) as well accelerated cell death (Cheah, Weigand \& Stark, 1987).

Under conditions where plasmid-carriage is dcleterious to the cell, evolutionary changes which result in an attenuation of the deleterious effect of the plasmids would be predicted from the application of classical predator-prey theory (Levin \& Lenski, 1983). Under long-term laboratory culture, changes in both the bacterial chromosome (Bouma \& Lenski, 1988; Modi \& Adams, 1991) and the plasmid (Godwin \& Slater, 1979; Modi \& Adams, 1991) have been reported which have resulted in a decreased deleterious effect 
of the plasmid. Evolutionary changes in the plasmid may involve base substitutions, but large deletions, which may reduce the maintenance cost of the plasmid and/or plasmid mediated interference substantially, will also be expected. Such macro-evolutionary changes have been observed in descendants of a gentamicin-resistance plasmid isolated from a nosocomial environment (Lee, Gerding \& Cleary, 1984).

In this communication, we describe and analyze structural changes occurring in a derivative of pBR322 during long-term growth in glucose-limited chemostat culture. In particular, we show that, i) a spontancous deletion occurred in the plasmid during growth under substrate-limiting conditions, ii) the strain carrying the plasmid with the deletion rapidly became predominant amongst the plasmid-containing strains in the population from which it was isolated, and iii) the deletion in the plasmid was responsible for most or all of the decrease in the deleterious effect of the plasmid.

\section{Materials and methods}

Growth media. Tryptone broth (TB) contained $5 \mathrm{~g}$ $\mathrm{NaCl}$ and $10 \mathrm{~g}$ tryptone (Difco) per liter. Tryptone agar was TB plus $1.4 \%(\mathrm{w} / \mathrm{v})$ agar. The minimal medium used was that of Davis and Mingioli (1950), lacking citrate and containing thiamine. $\mathrm{HCl}$ at $1 \mu \mathrm{g}$ $\mathrm{ml}^{-1}$. Carbon source in the form of $\mathrm{D}$-glucose was present at a concentration of $0.0125 \% \mathrm{w} / \mathrm{v}$ in chemostats and at $0.025 \% \mathrm{w} / \mathrm{v}$ in batch culture. The concentration of D-glucose gave population densities of approximately $1 \times 10^{8}$ organisms $\mathrm{ml}^{-1}$ when growth-limiting in chemostat culture. D-glucose (Sigma) and thiamine. $\mathrm{HCl}$ (Sigma) were sterilized by filtration through $0.22 \mu \mathrm{m}$ pore-size nitrocellulose membranes (Millipore GS) prior to use in the chemostat medium. After autoclaving the medium ampicillin was added, when necessary, to a concentration of $50 \mu \mathrm{g} \mathrm{ml}^{-1}$ for solid or liquid medium.

Organisms and plasmids. Escherichia coli JA104 and its derivatives were used (Table 1). Strain JA122 is strain JA104 transformed with the plasmid pBR322 $\Delta 5$, approximately $8.7 \mathrm{~kb}$ in size (Heffron, Kostriken, Morita \& Parker, 1981) and its derivatives (Table 1). Strain RIM101 was a plasmid-containing ampicillin- resistant clone obtained from single colonies appearing on TA plates after plating samples from the chemostat bacterial population after approximately 416 generations of growth in glucose-limited chemostat culture. To aid in the interpretation of the competition experiments, the bacterial chromosomes and plasmid replicons are denoted by the symbols $b_{0}$, $p_{0}$ etc.

A plasmid-free derivative of RIM101 was initially isolated by assaying colonies for $\beta$-lactamase using the

Table 1. Bacterial strains.

\begin{tabular}{|c|c|c|c|}
\hline \multirow[t]{2}{*}{ Strain } & \multirow[t]{2}{*}{ Relevant characteristics } & \multicolumn{2}{|c|}{$\begin{array}{l}\text { Replication } \\
\text { designation }\end{array}$} \\
\hline & & E.coli & Plasmid \\
\hline JA104 & $\begin{array}{l}\mathrm{F}^{-} \text {thi } 1 \text { lac } \mathrm{Y} 1 \text { araD139 } \\
\text { supE44 hss } 1 \text { lysogenic for } \lambda \\
\text { (Adams et al., 1979) }\end{array}$ & $b_{0}$ & \\
\hline $\begin{array}{l}\text { JA } 122 \\
\text { Original } \\
\text { Strain }\end{array}$ & $\begin{array}{l}\text { JA } 104 \text { transformed with plasmid } \\
\text { pBR322 } \Delta 5 \text { (Heffron et al., 1981); } \\
\text { ampicillin and tetracycline resistant }\end{array}$ & $b_{n}$ & $p_{0}$ \\
\hline RIM103 & $\begin{array}{l}\text { JA } 104 \text { transformed with the plasmid } \\
\text { isolated from RIM101; ampicillin } \\
\text { resistant }\end{array}$ & $b_{0}$ & $p_{t}$ \\
\hline RIM106 & $\begin{array}{l}\text { JA104 transformed with a derivative } \\
\text { of plasmid pBR } 322 \Delta 5 \text { containing } \\
\text { a } 2.14 \mathrm{~kb} \text { deletion (see Fig. } 2 \text { ); } \\
\text { ampicillin resistant }\end{array}$ & $b_{0}$ & $p_{2}$ \\
\hline RIM105 & $\begin{array}{l}\text { JA } 104 \text { transformed with a derivative } \\
\text { of plasmid pBR } 322 \Delta 5 \text { containing } \\
\text { a } 2.7 \mathrm{~kb} \text { deletion (see Fig. } 2 \text { ); } \\
\text { ampicillin resistant }\end{array}$ & $b_{0}$ & $p_{3}$ \\
\hline & $\begin{array}{l}\text { JA104 transformed with a derivative } \\
\text { of plasmid pBR } 322 \Delta 5 \text { containing }\end{array}$ & & \\
\hline CF 101 & $\begin{array}{l}\text { a } 0.6 \mathrm{~kb} \text { deletion of the region } \\
\text { defined by the unique HindIII and } \\
\text { Sall sites (see Fig. 2); ampicillin } \\
\text { resistant }\end{array}$ & $b_{0}$ & $p_{4}$ \\
\hline RIM101 & derivative of JA122 - evolved strain & & \\
\hline $\begin{array}{l}\text { Evolved } \\
\text { strain }\end{array}$ & $\begin{array}{l}\text { isolated after approximately } 416 \\
\text { generations of growth in glucose- } \\
\text { limited continuous culture; } \\
\text { ampicillin resistant }\end{array}$ & $b_{1}$ & $p_{1}$ \\
\hline RIMI02 & $\begin{array}{l}\text { Plasmid-free derivative of RIM101 } \\
\text { transformed with plasmid } \\
\text { pBR322 } \Delta 5 \text { (Heffron } \text { et al., 1981); } \\
\text { ampicillin and tetracycline resistant }\end{array}$ & $b_{l}$ & $p_{0}$ \\
\hline
\end{tabular}


iodometric assay described by Boyko and Ganschow (1982). Absence of the plasmid was confirmed by quantitative Southern analysis (Maniatis, Fritsch \& Sambrook, 1982), probing with plasmid DNA, and analyzing the blots with a laser-scanning densitometer (LKB Ultroscan XL). Plasmid-containing strains were obtained by transformation with purified plasmid DNA (prepared as described below) using the standard $\mathrm{CaCl}_{2}$ procedure. The presence of a plasmid in strains recovered from chemostat cultures was demonstrated by extracting the plasmid DNA by the alkaline lysis method and running the restriction endonuclease digested plasmid DNA on agarose gels stained with ethidium bromide (Maniatis, Fritsch \& Sambrook, 1982).

Long-term continuous culture. Cultures were inoculated with a single clone of JA122 and maintained in an aerated culture vessel at $30^{\circ} \mathrm{C}$ in minimal medium at a dilution rate, $D \approx 0.20$, equivalent to a cell generation time of approximately $3.5 \mathrm{~h}$ (Kubitschek, 1970). Periodically an aliquot of the cell suspension was frozen in $40 \%$ glycerol and stored at $-70 \mathrm{C}$ for later analysis.

Procedure for competition experiments in continuous culture. Chemostat cultures were maintained at $30^{\circ} \mathrm{C}$ in a glucose-limited minimal salt chemostat medium (Helling, Kinney \& Adams, 1981) in aerated culture vessels $120-195 \mathrm{ml}$ in volume, at the same dilution rate $\left(\mathrm{D} \approx 0.2 \mathrm{~h}^{-1}\right)$, used in the long-term continuous culture. The bacterial population density was monitored by measuring the culture absorbance at $550 \mathrm{~nm}$ in a Bausch and Lomb Spectronic 100 spectrophotometer. Two strains were first grown in batch mode for 14-18 $\mathrm{h}$, in minimal medium containing glucose and supplemented with ampicillin (Sigma), when necessary. Typically, the competition experiments were initiated by inoculating the chemostat with an equal number of cells from the batch cultures, of the two competing strains. Just before addition of the inoculum the outflow tubc of the chemostat was clamped, the cultures were allowed to mix adequately, and the clamp was then removed. Data collection commenced when numerical equilibrum (as determined by culture absorbance at $\mathrm{A}_{550}$ ) was attained. All competition experiments were terminated after 20-25 generations to avoid complications due to the occurrence of faster growing adaptive mutants (Helling, Vargas \& Adams, 1987).

Changes in the frequencies of the two competing strains were monitored by plating samples at appropriate dilutions on TA plates and replicating these onto TA plus ampicillin $\left(50 \mu \mathrm{g} \mathrm{ml}^{-1}\right)$ and TA plus ampicillin plus tetracycline $\left(10 \mu \mathrm{g} \mathrm{ml}^{-1}\right)$ plates. An average of 200 colonies was replicated for each sample. Changes in the total frequency of plasmidcontaining cells, were monitored from the ratio of the total number of colonies plated to the number of colonies appearing on TA plus tetracycline plates.

The number of cell generations was determined from $(D \times t) / \ln 2$, where $D$ is the dilution rate $\left(\mathrm{h}^{-1}\right)$ and $t$ is the time (h) since the beginning of the competition experiment (Kubitschek, 1970). Differences in the growth rates ( $\mu$ ) of the two strains, $i$ and $j,\left(\left|\mu_{i}-\mu_{j}\right|\right)$ were calculated by standard least square regression techniques after linearization of the frequencies with a logit transformation. The specific growth rates associated with the different genotypes were defined relative to a reference strain (strain 2) and are denotcd relative fitnesses following the convention in population genetics. The standard errors associated with the relative fitnesses must be regarded as approximate as the errors associated with the data points are unavoidably autocorrelated.

Plasmid and probe preparation. Plasmid DNA was prepared by the alkaline lysis procedure described in Maniatis, Fritsch and Sambrook (1982). Plasmid DNAs used as probes were purified either by two cycles of $\mathrm{CsCl}$-ethidium bromide density gradient centrifugation, or by using pZ523 spun columns for 5 Prime-3Prime Inc., with the procedure described by the vendor. The purified DNA was also used for all transformations and restriction endonuclease digestions.

Plasmid deletion construction. Procedures for plasmid deletion constructions described by Ausubel et al. (1989) were used. Partial digestion of pBR322 $\Delta 5$ plasmid DNA prepared from JA122, with EcoRV, produced linearized fragments of different lengths. The restriction endonuclease was heat inactivated $(75$ $\mathrm{C}$ for $10 \mathrm{~min}$ ) to stop the reaction, and the plasmid 
DNA then ethanol-precipitated and resuspended in sterile glass-distilled water to a final concentration of less than $0.1 \mu \mathrm{g} / \mathrm{ml}$. The blunt-ended plasmid DNA fragments were ligated using ligation buffer containing ATP and T4 ligase (0.06-0.09 units/ $\mu$ l of reaction mixture) at room temperature for about $6 \mathrm{~h}$. Partial digestions using restriction endonucleases and ligation reactions were checked by running the mixture on $0.7 \%$ agarose gels. The ligated plasmid DNA mixture was used to transform competent JA104 cells by the $\mathrm{CaCl}_{2}$ procedure (Maniatis, Fritsch \& Sambrook, 1982). To screen for plasmid deletions of interest, plasmid DNA was extracted from selected ampicillin resistant and tetracycline sensitive transformants as described above, and the resulting DNA samples were then analyzed by digestion with appropriate restriction endonucleases, using procedures as suggested by the manufacturer, and separation of the fragments by electrophoresis on $0.7 \%$ agarose 'submarine' gels (Maniatis, Fritsch \& Sambrook, 1982).

\section{Results}

A population, initiated from a single clone of $E$. coli containing a derivative of the plasmid pBR322 was maintained for approximately 650 generations in continuous culture, under chemostat conditions. The cell generation time was $3.5 \mathrm{~h}$, with growth limited by the concentration of glucose. Plasmid-containing cells constituted $100 \%$ of the population for approximately 100 generations, at which time plasmid-free cells increased rapidly in the population, until by generation 300 they constituted approximately $90 \%$ of the population. However, from generation 300 onwards, plasmid-containing cells never disappeared from the population completely but were maintained at frequencies varying between one and six percent. Some fluctuations in their frequency, indicative of periodic selection (Helling, Kinney \& Adams, 1981), were observed between generations 200 and 600 . During this time, differences in the frequencies of the two phenotypes, tetracycline-sensitive, ampicillin-resistance $\left(\right.$ tet $\left.^{\mathrm{s}}, \mathrm{amp}^{\mathrm{r}}\right)$ and tetracycline resistance, ampicillin-resistance (tet ${ }^{r}$, amp $^{r}$ ) became apparent. Figure 1 shows the frequency of tets ${ }^{\mathrm{s}} \mathrm{amp}^{\mathrm{r}}$ cells relative to the frequency of ampr cells in the population. It can be seen that the frequency of tet ${ }^{\mathrm{s}}$, amp cells increased steadily from $5 \%$ to $99 \%$ in the plasmid-containing sector of the population between 380 and 560 generations.

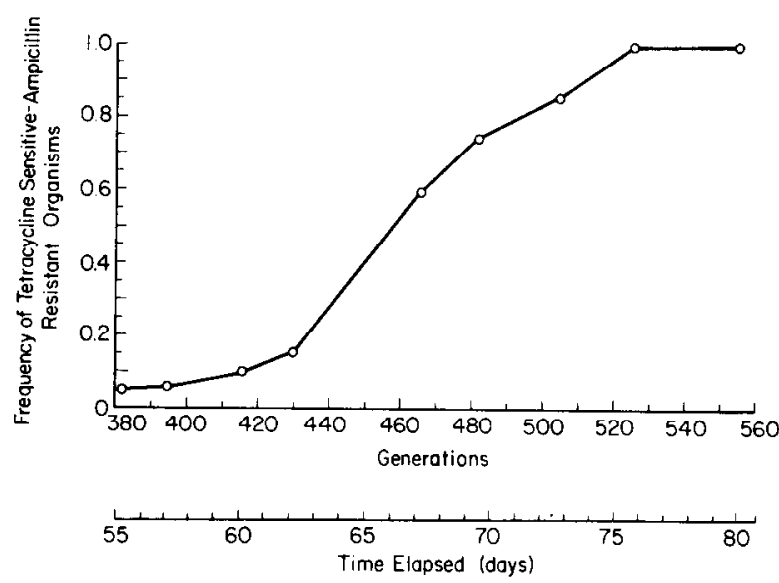

Fig. 1. Frequency of tetracycline-sensitive, ampicillin-resistant plasmid-containing organisms relative to the frequency of ampicillin-resistant organisms between generations 380 and 560 .

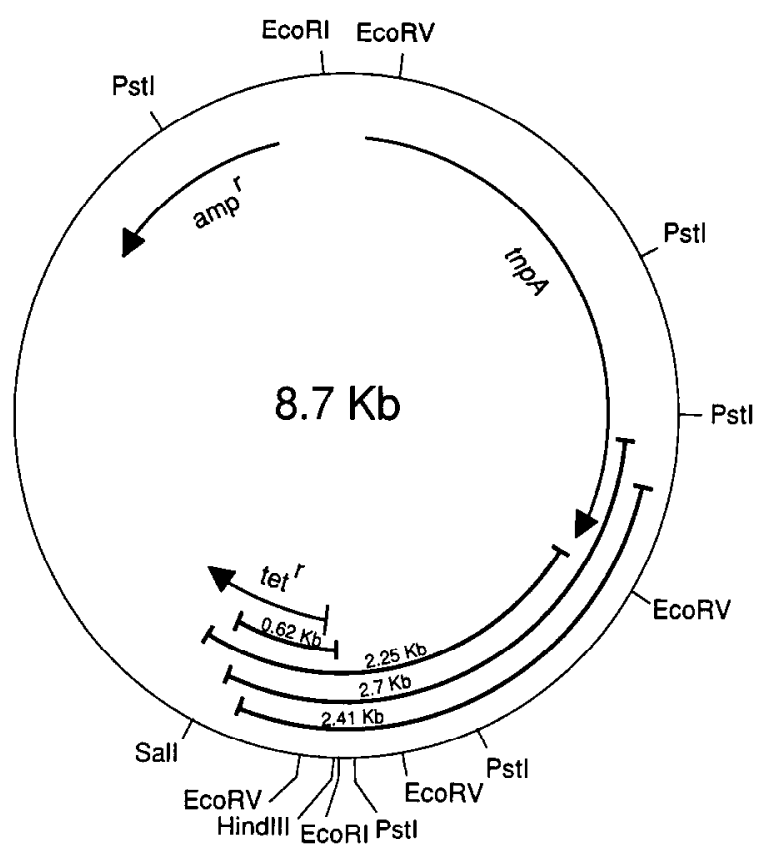

Fig. 2. Restriction map of the plasmid isolated from evolved strain RIM101, as well as three artificial plasmid deletion constructs, showing restriction sites for enzymes, EcoRI, EcoRV, HindIII, Pst I and $S a l l$. $2.25 \mathrm{~Kb}$ deletion - naturally occurring deletion. $0.6,2.4$, and $2.7 \mathrm{~Kb}$ deletions - artificially constructed deletions. The position and extent of the $t e t^{r}, a m p^{r}$ and $t m p A$ genes are shown by the arrows. The arrows also indicate the direction of transcription with the head of the arrow indicating the 3' end of the coding region. Details of the construction of the artificial deletions are given in the Materials and methods section. 
To determine the basis for the loss of tetracycline resistance, plasmid DNA was prepared from RIM101, a tet ${ }^{s}, \mathrm{amp}^{\mathrm{r}}$ clone, isolated after about 416 generations from this chemostat, and a restriction map constructed. This map (see Fig. 2), shows that the plasmid carried by RIM101 had suffered a $2.25 \mathrm{~kb}$ deletion, approximately one quarter of the plasmid, a region encompassing most of the tetracycline resistance operon, as well as a region upstream from the tetracycline gene of approximately $1.5 \mathrm{~kb}$. Plasmid DNA extracted from various other tet ${ }^{s}, a p^{r}$ strains from chemostat samples between generation 382 and 505 also showed the same restriction endonuclease digestion pattern. Thus, it can be concluded that the difference in the frequency between tet ${ }^{r}, \mathrm{amp}^{\mathrm{r}}$ and tet $\mathrm{t}^{\mathrm{s}}$, amp $^{r}$ isolates can be explained by the presence of this naturally occurring deletion plasmid in the population. The increase in the frequency of the deletion further suggested that the spontaneous deletion in the plasmid could decrease the deleterious effect of the plasmid in the host, such that cells carrying the deleted plasmid would increase in frequency relative to cells carrying the unmodified plasmid.

The deleterious effects of the unmodified plasmid and the plasmid carrying the naturally occurring deletion were compared by placing cells carrying these plasmids in direct competition in the same glucoselimited chemostat environment in which the naturally occurring deletion plasmid arose. To aid in the interpretation of these, and subsequent competition experiments, the various bacterial and plasmid chromosomes are denoted using the symbols $b_{0}, p_{0}$ etc. (see Table 1). The results shown in Table 2 express the

Table 2. Analysis of the effect of change in plasmid $p_{l}$ in different bacterial chromosome backgrounds.

\begin{tabular}{|c|c|c|c|}
\hline In background $b$ & & Strain 2 & $\begin{array}{l}\text { Fitness of strain } 2 \\
\text { relative to a value } \\
\text { of } 1 \text { for strain } 1 \\
\pm \text { SEM }\end{array}$ \\
\hline $\begin{array}{l}\mathrm{RIM} 102 b_{1}+p_{0} \\
\mathrm{RIM} 102 b_{1}+p_{0}\end{array}$ & $\otimes$ & $\begin{array}{l}\text { RIM101 } b_{l}+p_{1} \\
\operatorname{RIM} 101 b_{l}+p_{l}\end{array}$ & $\begin{array}{l}1.87 \pm 0.32 \\
1.51 \pm 0.19\end{array}$ \\
\hline \multicolumn{4}{|l|}{ In background $b_{n}$} \\
\hline $\begin{array}{l}\mathrm{JA} 122 b_{0}+p_{0} \\
\mathrm{JA} 122 b_{0}+p_{0}\end{array}$ & $\otimes$ & $\begin{array}{l}\operatorname{RIM} 103 b_{0}+p_{1} \\
\operatorname{RIM} 103 b_{0}+p_{1}\end{array}$ & $\begin{array}{l}1.17 \pm 0.04 \\
1.25 \pm 0.05\end{array}$ \\
\hline
\end{tabular}

results in terms of relative fitnesses, where a fitness of greater (or less than) than one denotes a competitive superiority (inferiority) for that strain, relative to the reference strain, which by convention is assigned a fitness of one. In both bacterial chromosome backgrounds, cells carrying the plasmid with the spontaneous deletion $p_{1}$ possess a large competitive advantage over cells carrying the original plasmid $p_{0}$. It is noteworthy that the fitness increment which can be attributed to the plasmid carrying the naturally occurring deletion, is significantly greater in the bacterial chromosome background $b_{1}$ in which it evolved than in the original background $b_{0}$. This indicates that the bactcrial and plasmid chromosomes have co-evolved to maximize fitness.

These results do not distinguish between a decrease in the deleterious effect of the plasmid, $p_{l}$, caused by the gross deletion and a decrease in the deleterious effect due to structural changes within the plasmid, independent of the deletion. To determine the role of the deletion in the fitness increments observed, strains were constructed containing artificially induced dele-

Table 3. Reconstruction of plasmid change.

\begin{tabular}{lll}
\hline Strain 1 & Strain 2 & $\begin{array}{l}\text { Fitness of strain 2 } \\
\text { relative to a value } \\
\text { of 1 for strain 1 } \\
\pm \text { SEM }\end{array}$ \\
Plasmid construct $1-2.4$ kb deletion & \\
\hline JA122 $b_{n}+p_{0}$ & $\begin{array}{l}\text { RIM106 } b_{0}+p_{2} \\
\text { JA122 } b_{0}+p_{0}\end{array}$ & $1.22 \pm 0.03$ \\
JA122 $b_{0}+p_{0}$ & $\begin{array}{l}\text { RIM106 } b_{0}+p_{2} \\
\text { RIM106 } b_{0}+p_{2}\end{array}$ & $1.11 \pm 0.01 \pm 0.06$ \\
\hline
\end{tabular}

Plasmid construct 2-2.7 kb deletion

\begin{tabular}{llll}
\hline JA122 $b_{\theta}+p_{0}$ & $\bigotimes$ & RIM105 $b_{0}+p_{3}$ & $1.13 \pm 0.01$ \\
JA122 $b_{\theta}+p_{0}$ & $\bigotimes$ & RIM105 $b_{0}+p_{3}$ & $1.08 \pm 0.01$ \\
JA122 $b_{\theta}+p_{0}$ & $\otimes$ & RIM105 $b_{0}+p_{3}$ & $1.08 \pm 0.01$
\end{tabular}

Plasmid construct 3-0.6 kb deletion

\begin{tabular}{lllll}
\hline $\mathrm{JA} 122 b_{0}+p_{n} \otimes$ & $\mathrm{CF} 101$ & $b_{0}+p_{4}$ & $1.13 \pm 0.03$
\end{tabular}

$\begin{array}{lllll}\mathrm{JA} 122 b_{0}+p_{0} \otimes & \text { CFIOI } & b_{0}+p_{4} & 1.08 \pm 0.01\end{array}$

Fffect of plasmid pRR $322 \Delta 5\left(n_{0}\right)^{*}$

\begin{tabular}{lllll}
\hline $\mathrm{JA1} 122 b_{0}+p_{0}$ & $\bigotimes$ & $\mathrm{JA} 104$ & $b_{0}$ & $1.19 \pm 0.05$ \\
$\mathrm{JA1} 22 b_{0}+p_{0}$ & $\bigotimes$ & $\mathrm{JA104}$ & $b_{0}$ & $1.17 \pm 0.06$ \\
$\mathrm{JA1} 22 b_{0}+p_{0}$ & $\bigotimes$ & $\mathrm{JA} 104$ & $b_{0}$ & $1.14 \pm 0.03$
\end{tabular}

* Data from Modi and Adams (1991). 
tions, and placed in competition with strains that were isogenic except for the deletions. Plasmid deletions were induced using the procedures described in the Materials and methods section, and were screened for deletions that were approximately the same size and location as the naturally occurring deletion in the plasmid, $p_{1}$. In addition, a plasmid was isolated with a much smaller $(0.6 \mathrm{~kb})$ deletion of the region defined by the unique SalI and HindIII sites. Deletion of this region of the plasmid, removes approximately $40 \%$ of the coding sequence of the tetracycline reistance protein, plus 57 nucleotides 5 ' to the initiation of transcription (Peden, 1983). Insertion of DNA into cither the SalI or the HindIII site causes loss of tetracycline resistance (Peden, 1983). As expected, cells carrying any one of these three plasmids are tet ${ }^{\mathrm{s}}$, ampr. The restriction maps of these plasmids (denoted $p_{2}, p_{3}$ and $p_{4}$ ) are shown in Figure 2 together with that of the naturally occurring plasmid, $p_{l}$.

The results of the competition experiments, presented in Table 3, show that in all three cases, deletion of a section of the plasmid chromosome produced significant fitness increments of between $10 \%$ and $25 \%$. The increments in fitness which can be ascribed to the naturally occurring deletion and the three artificially constructed deletions are not significantly different, and are unrelated to the size of the deleted region. Deletion and inactivation of a portion of the tetracycline resistance coding locus, resulted in a fitness increment equivalent to those for deletions three to four times larger. We therefore conclude that the $2.25 \mathrm{~kb}$ spontaneous deletion in the plasmid accounted for a great majority of the decrease in the deleterious effect of the evolved plasmid, $p_{l}$, and the consequent predominance of cells carrying this plasmid in the plasmid bearing sector of the population. In addition, the results strongly implicate the tetracycline resistance locus as the principal factor determining the selective increments which can be ascribed to the plasmid deletions.

\section{Discussion}

A substantial amount of evidence has now accumulated suggesting that the bacterial genome can undergo major changes in structure at a surprisingly high frequency. For example, in Salmonella typhimurium duplications can occur at a frequency of as high as $1 \times$ $10^{-3}$ and can include large amounts of the genome (Anderson \& Roth, 1977). At the same time, these duplications are quite unstable, being lost a high frequency under nonselective conditions (Roth \& Schmid, 1981). A number of studies have now shown that duplications are often selected in populations adapting to conditions of nutrient limitation (e.g., Horiuchi, Horiuchi \& Novick, 1963; Rigby, Burleigh \& Hartley, 1974; Sonti \& Roth, 1989), as well as to conditions which favor activity of a specific enzyme (e.g., Tisty, Albertini \& Miller, 1974; Edlund \& Normark, 1981; Jcssop \& Clugston, 1985). It has becn suggested that the lability of the bacterial genome in this respect may be an important evolutionary strategy by which bacteria adapt to changing environmental conditions (Anderson \& Roth, 1977).

Much less is known however, concerning the frequency and evolutionary significance of the obverse of gene duplications, namely gene deletions. Although comparison of sequences from related species suggests a role for deletions in generating evolutionary change (e.g., Hwu et al., 1986) we are aware of only one study that has documented the selection of a deletion during adaptation to nutrient limited conditions (Miller et al., 1984). The results presented in this paper show that deletion of a substantial portion of the plasmid chromosome may increase fitness significantly by attenuating the deleterious effect of the plasmid. The deletion encompassed most of the tetracycline operon as well as $1.5 \mathrm{~kb}$ upstream of this region, and rendered cells carrying this plasmid tetracycline sensitive. In earlier studies, Godwin and Slater (1979) and Noack et al. (1981) had reported the predominance over time of tetracycline sensitive plasmid derivatives, but in neither case was the molecular basis of the tetracycline sensitivity identified.

The deleterious effect associated with the carriage of plasmid DNA can be ascribed to either the maintenance cost of the plasmid and/or plasmid-mediated interference. The maintenance cost can be defined as the energy cost to the cell incurred by the replication and transcription of plasmid DNA, and the translation of plasmid-encoded proteins (Godwin \& Slater, 1979; Helling, Kinney \& Adams, 1981), whereas plasmid-mediated interference can be defined as the 
cost due to detrimental effects on the basic cellular structure or process due to presence of the plasmid (Helling, Kinney \& Adams, 1981; Boe, Gerdes \& Molin, 1987). The magnitude of the selective effect associated with a deletion of approximately one quarter of the plasmid suggests that plasmid-mediated interference, rather than maintenance cost, is the major cause of the selective reduction associated with the deletion. The selective disadvantage associated with the plasmid pBR322 $\Delta 5\left(p_{0}\right)$ has been determined to be 0.14-0.19 under the same conditions (see Table 3). Thus, if the selective disadvantage associated with plasmid carriage were solely due to simple energetic considerations, the difference in the relative fitness of the two plasmids would be expected to be 0.04-0.05 (1/4 $\times 0.14-0.19)$, whereas, the values calculated from the competition experiments are approximately fourfold larger. The similarity of the selective increments for the naturally occurring deletion, and the much smaller deletion covering the first $40 \%$ of the coding region of the tetracycline resistance gene, strongly implicate this region as the principal factor reducing the delctcrious effect of the plasmid. Our results do not allow us to distinguish between an increment in fitness caused by the mere presence of the tetracycline resistance locus, or by its expression. However, two independent sources of information strongly implicate expression as being responsible for the deleterious effect. i) The tetracycline operon is constitutively expressed in pBR322 (Tait \& Boyer, 1978), and overproduction of the tet $A$ protein has been shown to result in cell death and loss of membrane potential (Eckert \& Beck, 1989). Furthermore, under glucoselimited continuous culture conditions, plasmid copy number is greatly elevated (Modi \& Adams, 1991; see also Chao \& Bremer, 1986a, h; Taxis du Poet, 1987) which would result in overproduction of the tetA protein. ii) Expression, but not the presence of the tetracycline resistance operon has been shown to be selectively deleterious by Lee and Edlin (1985) and Nguyen et al. (1989). The magnitude of the selective differences that we observed are on the same order of magnitude as those seen by Lee and Edlin (1985) for chemostat culture, though they are significantly larger than those determined by Nguyen et al. (1989) who assayed selective differences only under batch culture conditions.

\section{Acknowledgements}

We thank F. Heffron for the gift of plasmid pBR322 $\Delta 5$, and R. A. Bender, D. Clewell, R. B. Helling for helpful discussion. This work was supported in part by the National Institutes of Health grant GM30959.

\section{References}

Anderson, R. P. \& Roth, J. R., 1977. Tandem genetic duplications in phage and bacteria. Ann. Rev. Microbiol. 31: 473-505.

Ausubel, F. M., Brent, R., Kingston, R. E., Moore, D. D., Seidman, J. G., Smith, J. A. \& Struhl, K., 1989. Current Protocols in Molecular Biology, Vol. I. Greene Publishing Associates and Wiley-Interscience.

Boe, L., Gerdes, K. \& Molin, S., 1987. Effects of genes exerting growth inhibition and plasmid stability on plasmid maintenance. J. Bacteriol. 169: 4646-4650.

Bouma, J. E. \& Lenski, R. E., 1988. Evolution of a bacteria/plasmid association. Nature 335: 351-352.

Boyko, W. L. \& Ganschow, R.E., 1982. Rapid identification of Escherichia coli transformed by pBR 322 carrying inserts at the PstI site. Anal. Biochem. 122: 885-888.

Chao, L. \& Bremer, H., 1986a. Effect of the bacterial growth rate on replication control of plasmid pBR322 in Escherichia coli. Mol. Gen. Genet. 203: 143-149.

Chao, L. \& Bremer, H., 1986b. Effect of relA function on the replication of plasmid pBR322 in Escherichia coli. Gen. Genet. 203: 150-153.

Cheah, U.E., Weigand, W.A. \& Stark, B.C., 1987. Effects of recombinant plasmid size on cellular processes in Escherichia coli. Plasmid 18: 127-134.

Chiang, C.S. \& Bremer, H., 1988. Stability of pBR322-derived plasmids. Plasmid 20: 207-220.

Eckert, B. \& Beck, C.F., 1989. Overproduction of transposon Tn10-encoded resistance protein results in cell death and loss of membrane potential. J. Bacteriol. 171: 3557-3559.

Edlund, T. \& Normark, S., 1981. Recombination between short DNA homologies causes tandem duplication. Nature 292: 269-271.

Engberg, B. \& Nordstrom, K., 1975. Replication of R-factor R1 in Escherichia coli K12 at different growth rates. J. Bacteriol. 123: 179-186.

Godwin, D. \& Slater, J. H., 1979. The influence of the growth environment on the stability of a drug resistance plasmid in Escherichia coli K12. J. Gen. Microbiol. 111: 201-210.

Heffron, F., Kostriken, R., Morita, C. \& Parker, R., 1981. Tn3 encodes a site-specific recombination system: identification of essential sequences, genes, and the actual site of recombination. Cold Spring Harbor Symp. Quant. Biol. 45: 259268.

Helling, R. B., Kinney, T. \& Adams, J., 1981. The maintenance of plasmid-containing organisms in populations of Escherichia coli. J. Gen. Microbiol. 123: 129-141.

Helling, R. B., Vargas, C.N. \& Adams, J., 1987. Evolution of Escherichia coli during growth in a constant environment. Genetics 116: 349-358. 
Horiuchi, T., Horiuchi, S. \& Novick, A., 1963. The genetic basis of hypersynthesis of $\beta$-galactosidase. Genetics 48: 157-169.

Hwu, H. R., Roberts, J. W., Davidson, E. H. \& Britten, R. J. 1986. Insertion and/or deletion of many repeated DNA sequences in human and higher ape cvolution. Proc. Nat. Acad. Sci. USA 83: 3875-3879.

Inselburg, J., 1978. ColE1 plasmid mutants affecting growth of an Escherichia coli recB recC sbcB mutant. J. Bacteriol. 133: 433-436.

Jessop, A. P. \& Clugston, C., 1985. Amplification of the ArgF region in strain HfrP4X of E. coli K12. Mol. Gen. Genet. 201: 347-350.

Jones, I. M., Primrose, S. B., Robinson, A. \& Ellwood, D. C., 1980. Maintenance of some ColEl-type plasmids in continuous culture. Mol. Gen. Genet. 180: 579-584.

Kubitschek, H.E., 1970. Introduction to Research with Continuous Cultures. Prentice-Hall Inc., Englewood Cliffs, New Jersey.

Lee, S. W. \& Edlin, G., 1985. Expression of tetracycline resistance in pBR322 derivatives reduces the reproductive fitness of plasmid-containing E. coli. Gene 39: 173-180.

Lee, S. C., Gerding, D. N. \& Cleary, P. P., 1984. Plasmid macroevolution in a nosocomial environment; demonstration of a persistent molecular polymorphism and construction of a cladistic phylogeny on the basis of restriction data. Mol. Gen. Genet. 194: 173-178.

Levin, B. R. \& Lenski, R. E., 1983. Coevolution in bacteria and their viruses and plasmids, pp. 99-127. In: Coevolution. Edited by D. J. Futuyma and M. Slatkin. Sinauer Assoc., Sunderland, Mass.

Lundquist, P. D. \& Levin, B. R., 1986. Transitory depression and the maintenance of conjugative plasmids. Genetics 113:483-497.

Maniatis, T., Fritsch, E. F. \& Sambrook, J., 1982. Molecular Cloning - A Laboratory Manual. Cold Spring Harbor Laboratories, Cold Spring Harbor, New York.

Melling, J., Ellwood, D.C. \& Robinson, A., 1977. Survival of R-factor carrying Escherichia coli in mixed cultures in the chemostat. FEMS Microbiol. Lett. 2: 87-89.

Miller, R. D., Dykhuizen, D. E., Green, L. \& Hartl, D. L., 1984. Specific deletion occurring in the directed evolution of 6phosphogluconate dehydrogenase in Escherichia coli. Genetics 108: 765-772.

Modi, R. I. \& Adams, J., 1991. Coevolution in bacterial-plasmid populations. Evolution 45: 656-667.

Nguyen, T. N. M., Phan, Q. G., Duong, L. P., Bertrand, K. P. \& Lenski, R. E., 1989. Effects of carriage and expression of the In 10 tetracycline-resistance operon on the fitness of $\mathrm{E}$. coli K 12 . Mol. Biol. Evol. 6: 213-225.
Noack, D., Roth, M., Guether, R., Muller, G., Undisz, K., Hoffmeier, C. \& Gaspar, S., 1981. Maintenance and genetic stability of vector plasmids pBR322 and pBR325 in Escherichia coli K12 strains grown in a chemostat. Mol. Gen. Genet. 184: 121-124.

Peden, K.W.C., 1983. Revised sequence of the tetracyclineresistance gene of pBR322. Gene 22: 277-280.

Rigby, P.W. J., Burleigh, B. D. \& Hartley, B.S., 1974. Gene duplication in experimental enzyme evolution. Nature 251: 200-204.

Roth, J. R. \& Schmid, M., 1981. Arrangement and rearrangement of the bacterial genome. Stadler symp. 13: 53-70.

Roth, M., Muller, G. \& Noack, D., 1980. Loss of the multi-copy resistance plasmid pBR325 from Escherichia coli CY2354 pBR325 during continuous cultivation, pp. 143-146. In: Fourth International Symposium on Antibiotic Resistance. Edited by $S$. Mitsuhasi, I. Rosival and V. Krcmery. Aviceneum Prague and Springer-Verlag West, Berlin.

Sonti, R. V. \& Roth, J. R., 1989. Role of gene duplication in the adaptation of Salmonella typhimurium to growth on limiting carbon sources. Genetics 123: 19-28.

Tait, R. C. \& Boyer, H. W., 1978. On the nature of tetracycline resistance controlled by the plasmid pSC101. Cell 13: 73-81.

Taxis Du Poet, P., Arcand, Y., Bernier, R. Jr., Barbotin, J.-N. \& Thomas, D., 1987. Plasmid stability in immobilized and free recombinant E. coli JM105(pKK223-200): Importance of oxygen diffusion, growth rate, and plasmid copy number. Appl. Environ. Microbiol. 53: 1548-1555.

Tlsty, D. T., Albertini, A. M. \& Miller, J. H., 1984. Gene amplification in the lac region of E. coli. Cell 37: 217-224.

Warnes, A. \& Stephenson, J. R., 1986. The insertion of large pieces of foreign genetic material reduces the stability of bacterial plasmids. Plasmid 16: 116-123.

Weinberger, M. \& Helmstetter, C. E., 1979. Chromosome replication and cell division in plasmid-containing E. coli B/R. J. Bacteriology 137: 1151-1157.

Wouters, J. T. M., Driehuis, F. L., Polaczek, P. J., van Oppenraay, M.-L. H. A. \& van Andel, J. G., 1980. Persistence of the pBR322 plasmid in Escherichia coli K12 grown in chemostat cultures. Antonie van Leeuwenhoek, Jour. Microbiol. Serol. 45: 353-362.

Wouters, J. T. M. \& van Andel, J. G., 1979. R-plasmid persistance in Escherichia coli grown in chemostat cultures. Antonie van Leeuwenhoek, Jour. Microbiol. Serol. 45: 317-318.

Zund, P. \& I ebek, G., 1980. Generation time-prolonging R plasmids: Correlation between increases in the generation time of Escherichia coli caused by R-plasmids and their molecular size. Plasmid 3: 65-69. 